Mirosław J. Leszka (Łódź)

(iD) https://orcid.org/0000-0003-2643-4520

\title{
The Arabs in the Chronicle of Constantine Manasses*
}

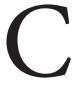
onstantine Manasses is the author of Synopsis Chronike, a chronicle that is written in verse and spans the period from the creation of the world until the year 1081 (the death of emperor Nikephoros Botaneiates). Our knowledge about him is limited. We do not know the exact dates of his birth or death. According to Elizabeth Jeffreys he was born in ca. 1120 and died some time after $1175^{1}$. It could be reasoned that he held no church function (in older literature on the subject he is recognised as the metropolitan of Naupaktos from the year $1187^{2}$ ) or state function. He was associated with the Constantinopolitanian literary community. Also, he had patrons - the sebastokratorissa Irene, wife of Andronikos ${ }^{3}$, brother of emperor Manuel I (1143-1180), as well as the sebastos John Contostephanus, nephew of Manuel $\mathrm{I}^{4}$. We know that he accompanied the latter during a mission
\end{abstract}

\footnotetext{
* This article has been written under the research project financed by the National Science Centre (Poland), decision number: DEC-2016/23/B/HS3/01 891 (Muhammad and the Origin of Islam - Stereotypes, Knowledge and Notions in the Byzantine-Russian Culture).

${ }^{1}$ Four Byzantine Novels. Agapetus - Theodore Prodromos. Rhodanthe and Dosikles - Eumathios Makrembolites. Hysmine and Hysminias. Constantine Manasses. Aristandros and Kallithea - Niketas Eugenianos, Drosilla and Charikles, trans. et praef. E. Jefrereys, Liverpool 2012, p. 274. Some most recent writing on Constantine Manasses: L. Neville, Guide to Byzantine Historical Writing, coll. D. Harrisville, I. Tamarkina, C. Whatley, Cambridge 2018, p. 200-204; L. Yuretich, Introduction, [in:] The Chronicle of Constantine Manasses, trans. et praef. EADEM, Liverpool 2018, p. 1-3.

${ }^{2}$ This was postulated by N. BeEs, Manassis, der Metropolit von Naupaktos ist identisch mit dem Schriftseller Konstantinos Manassis, BNJ 7, 1928/1929, p. 119-130. Some arguments against the postulate can be found in: O. LAMPsidis, Zur Biographie von Konstantinos Manasses und zur seiner Chronike synopsis (CS), B 58, 1988, p. 97-111; see also L. YUReTich, Introduction ..., p. 1; L. Neville, Guide..., p. 201.

${ }^{3}$ Andronikos died in ca. 1142. In addition to Constantine Manases, Irene's literary circle included John Tzetzes, Theodore Prodromos as well as the monk Jacob and Manganeios Prodromos. For more information about Irene and her literary circle see e.g. O. LAMPsIDIs, Zur Sebastokratorissa Eirene, JÖB 34, 1984, p. 91-105; E. JefFreYs, Sevastokratissa Eirene as Patron, WJK 61/62, 2011/2012, p. 177-194. ${ }^{4}$ P. Magdalino, In Search of the Byzantine Courtier: Leo Choirosphaktes and Constantine Manasses, [in:] Byzantine Court Culture from 829 to 1204, ed. H. MAGuire, Washington 1997, p. 161-162; M. Markovich, The "Itinerary" of Constantine Manasses, ICS 12, 2, 1987, p. 277.
} 
to Jerusalem in 1160 which was described in his Hodoiporikon ${ }^{5}$. He authored prose and poetry ranging from eulogies (e.g. in honour of Manuel Komnenos) to romances (Aristander and Kallitea whose mere fragments survived) ${ }^{6}$.

Synopsis Chronike $e^{7}$ was commissioned by the sebastokratorissa Irene, mentioned above, possibly between 1145 and $1148^{8}$. The first author to ever refer to Synopsis was Michael Glycas (who died in the 1180s) in Biblos Chronike. Synopsis was written in decapentasyllabic verse (political verse ${ }^{9}$ ). The edition by Odysseus Lampsidis comprises 6620 lines. In the process of writing it, Manasses used the works of different authors, with their truthfulness as the key selection criterion $^{10}$. Other than this general declaration, Manasses did not mention any of those authors by name. Scholars claim that his sources included the works of Dionysius of Halicarnassus, John the Lydian, John of Antioch, John Malalas, Theophanes, George Hamartolus, George Kedrenos and Joannes Zonaras ${ }^{11}$. We also know that he referred to his own work, in particular Aristander and Kallitea.

In all likelihood, the Chronicle was popular both in Byzantium and beyond. This is supported by the large number of manuscripts that have remained (over $100^{12}$ ) as well as the fact that it had its prose version ${ }^{13}$. The popularity and significance

\footnotetext{
${ }^{5}$ K. Horna, Das Hoidonporikon des Konstantinos Manasses, BZ 13, 1904, p. 313-355; E. GorI, Lo Hodoiporikon di Constantino Manasse, 2011 (= Porph 8, ottobre 2011. Supplemento 12); see also M. Markovich, The "Itinerary"..., p. 277-291.

${ }^{6}$ More about the output of Constantine Manasses can be found among others in P. Magdalino, In Search..., p. 161-164; E. Gori, Lo Hodoiporikon..., p. 3-12; I. Nilsson, Narrating Images in Byzantine Literature: the Ekphraseis of Konstantinos Manasses, JÖB 55, 2005, p. 121-146; EADEM, Constantine Manasses, Odysseus and the Cyclops: On Byzantine Appreciation of Pagan Art in the Twelfth Century, Bsl 69, 2011, p. 123-136.

${ }^{7}$ Edition: Constantini Manassis Breviarium Chronicum, vol. I-II, rec. O. Lampsidis, Athenis 1996 [CFHB, 36.1-2] (cetera: Synopsis Chronike). For information about the chronicle see among others: I. Nilsson, Discovering Literariness in the Past: Literature vs. History in the Synopsis Chronike of Konstantinos Manasses, [in:] L'écriture de la mémoire. La litterarité de l'historiographie. Actes du colloque international sur la littérature byzantine, Nicosie 6-8 mai 2004, ed. P. Odorico, P.A. Agapitos, M. Hinterberger, Paris 2006 [= DByz, 6], p. 15-31; I. Nilsson, E. Nystrom, To Compose, Read, Use a Byzantine Texts: Aspects of the Chronicle of Constantine Manasses, BMGS 33, 2009, p. 42-60; В.Ю. ЖАРКАЯ, Несколько замечаний о сложных эпитетах у Константина Манассии, АДСВ 44, 2016, p. 178-190; I. TAXIDIs, Ekphraseis of Persons with Deviatonal Behavior in Constantine Manasses' Synopsis Chronike, Bv 35,2017 , p. 145-159.

${ }^{8}$ According to: E. Jeffreys, Four..., p. 273-274. Other variants: L. YURETich, Introduction..., p. 3, note 17; I. Nilsson, The Past as Poetry: Two Byzantine World Chronicles in Verse, [in:] A Companion to Byzantine Poetry, ed. W. Hörandner, A. Rhoby, N. ZagkLas, Leiden-Boston 2019, p. 517-538.

${ }^{9}$ More on political verse can be found in: M. Jeffreys, The Nature and Origins of the Political Verse, DOP 28, 1974, p. 141-195.

${ }^{10}$ Synopsis Chronike, 23-24.

${ }^{11}$ L. Neville, Guide..., p. 200; L. Yuretich, Introduction..., p. 7.

${ }^{12}$ O. LAmpsidis, Eıৎ $\alpha \gamma \omega \gamma \eta$, [in:] Constantini Manassis..., p. LXXVI-CXLIX; I. NILsson, E. NYstrom, To Compose..., p. 43; L. Yuretich, Introduction..., p. 4; L. Neville, Guide..., p. 200.

${ }^{13}$ K. Praechter, Eine vulgärgriechische Paraphrase der Chronik des Konstantinos Manasses, BZ 4, 1895, p. 272-313; IDEM, Zur vulgären Paraphrase des Konstantinos Manasses, BZ 7, 1898, p. 588-593.
} 
of the text is also evidenced by its $14^{\text {th }}$ century translation into Middle Bulgarian, commissioned by the tsar of Bulgaria Ivan Alexander (1331-1371). The translator annotated the Chronicle using glosses with basic information on Bulgarian rulers. The translation was most likely created in Veliko Tărnovo in the period 1335-1340. We know three manuscripts coming from the territory of Bulgaria: two dating from the half of the $14^{\text {th }}$ century (now at the State Historical Museum in Moscow $^{14}$, the second one in the Vatican Library ${ }^{15}$ ) and one dating from the $16^{\text {th }}$ century (currently at the library of the Romanian Academy ${ }^{16}$ ). The translation of the work by Constantine Manasses, done in Bulgaria, gained popularity in the Slavic world. Its copies survived in Ruthenian (3 from the $17^{\text {th }}$ century) as well as Serbian (from the $16^{\text {th }}$ century ${ }^{17}$ ). Contemporary researchers consider the Bulgarian translation to be of high quality. It is seen as a landmark in the development of Bulgarian literary language ${ }^{18}$.

This paper looks into the piece by Constantine Manasses considering how it depicts the Arabs. As is commonly known, starting from the fourth decade of the $7^{\text {th }}$ century they were a highly dangerous enemy of the Byzantines and they remained so for a few centuries ${ }^{19}$.

\footnotetext{
${ }^{14}$ Created by a monk whose name was Philip.

${ }^{15}$ Codex Vaticanus slav. II. comprises 206 pages, 69 of which contain miniatures. Среднеболгарский перевод хроники Константина Манассии в славянских литературах, еd. Д.С. Лихачев, София 1988; E.N. Boeck, Displacing Byzantium, Disgracing Convention: the Manuscript Patronage of Tsar Ivan Alexander of Bulgaria, Manu 51, 2, 2007, p. 181-208; EADEM, Imagining the Byzantine Past. The Perception of History in the Illustrated Manuscripts of Skylitzes and Manasses, Cambridge 2015; EADEM, The Vatican Manasses as a Curated Display of Universal History, [in:] Laudator temporis acti. Studia in memoriam Ioannis A. Božilov, vol. II, Ius, imperium, potestas, litterae, ars et archeologia, ed. I. Biliarsky, Serdicae 2018, p. 419-431.

${ }^{16}$ L. YURETICH, Introduction..., p. 5.

${ }^{17}$ Ibidem, p. 5-6.

${ }^{18}$ Среднобългарский перевод Хроники..., раssim. Хрониката на Константин Манаси. Зората на българската епика, ed. et trans. И. Буюклиев, сотm. И. Божилов, София 1992, p. 1-42. It should be pointed out that the author of the Slavic translation largely retained the spirit of the Greek original.

${ }^{19}$ It should be remembered that Byzantine-Arab contacts were found earlier as well (see e.g.: L.I. Conrad, The Arabs to the Time of the Prophet, [in:] The Cambridge History of the Byzantine Empire c. 500-1492, ed. J. ShePard, Cambridge 2007, p. 173-195; T. WolińsKa, Difficult Neighbours, Enemies, Partners, Allies, [in:] Byzantium and the Arabs. The Encounter of Civilizations from Sixth to Mid-Eighth Century, ed. EAdem, P. FilipCzaK, Łódź 2015 [= BL, 22], p. 150-203. Basic information about Byzantine-Arab relations in the period covered by Synopsis Chronike can be found among others in: G. Ostrogorski, Dzieje Bizancjum, trans. H. Evert-Kappesowa et al., Warszawa 1968; А.А. ВАсильЕв, Византия и арабы. Политические отночения за время Македонской династии (867-959), Санкт-Петербург 1902; W.E. KAEGI, Confronting Islam: Emperors versus Caliphs (641c. 850), [in:] The Cambridge History..., p. 365-394; H. Kennedy, The Great Arab Conquests. How the Spread of Islam Changed the World We Live in, London 2007.
} 
The first reference to the Arabs has to do with the reign of emperor Leontius $(695-698)^{20}$. Constantine Manasses states that Africa was invaded by plunderers descending from Hagarenes ${ }^{21}$. The emperor considered the danger to be serious and took action. Despite initial successes of the Romans (Byzantines), Carthage, the capital of North Africa, was conquered and pillaged by the Arabs who are described by the historian as savage, cruel and bloodthirsty beasts. We also learn from Manasses here that the Arabs had a large fleet ${ }^{22}$.

The second reference appears in relation to emperor Anastasios II (713-715) ${ }^{23}$. We learn that the emperor sent Byzantine ships against the fleet of "Hagarene pirates" 24 . During that expedition a mutiny took place against the emperor and Theodosius, formerly a tax collector, was proclaimed as the new ruler ${ }^{25}$.

The third reference can be identified in relation to emperor Michael II. However, in this case the Arabs are not the subject but are brought in to build a negative image of the emperor himself, as Constantine Manasses did not hold him in high esteem due to the fact that Michael was an iconoclast. The historian writes as follows: He erred in not a few battles and revealed himself as an object of derision and ridicule to the Hagarenes ${ }^{26}$.

Another mention of the Arabs - this time with respect to the reign of Michael III (842-867) - offers no clues as to what attitude Manasses had towards them and gives us no evidence about the group itself ${ }^{27}$.

After the reign of Michael III the Arabs are mentioned by Constantine Manasses only in the context of events during the reign of Romanos II (959-963), and then Nikephoros Phokas (963-969), John I Tzimiskes (969-976) and finally Basil II (976-1025).

\footnotetext{
${ }^{20}$ For more about the Byzantine-Arab strife see: W.E. KAEgI, Muslim Expansion and Byzantine Collapse in North Africa, Cambridge 2010.

${ }^{21}$ More about terms used to refer to Arabs can be found in: T. WolińskA, Arabs, (H)agarenes, Ishmaelites, Saracens - a Few Remarks about Naming, [in:] Byzantium..., p. 22-37.

22 Synopsis Chronike, 3834-3849.

${ }^{23}$ For more about the Byzantine-Arab relations during the reign of Anastasios see: B. СесотA, Arabskie oblężenia Konstantynopola w VII-VIII wieku. Rzeczywistość i mit, Łódź 2015 [= BL, 21], p. 106-107.

${ }^{24}$ Synopsis Chronike, 4054-4057.

${ }^{25}$ For more information about the mutiny see: G.V. Sumner, Phillipicus, Anastasius II and Theodosius III, GRBS 17, 1976, p. 291-292; W.E. KAEGI, Byzantine Military Unrest. An Interpretation, Amsterdam 1981, p. 191-193; W. Treadgold, Seven Byzantine Revolutions and the Chronology of Theophanes, GRBS 31, 1990, p. 214.

${ }^{26}$ Synopsis Chronike, 4636-4637 (The Chronicle of Constantine Manasses, p. 187). For more information about Byzantine-Arab relations during the reign of Michael II see: G. Ostrogorski, Dzieje Bizancjum..., p. 183-184.

${ }^{27}$ Synopsis Chronike, 5200sqq. For more about the Byzantine-Arab relations during the reign of Michael III see: G. Ostrogorski, Dzieje Bizancjum..., p. 197.
} 
When it comes to the reign of Romanos $\mathrm{II}^{28}$, the Arab theme is related to Nikephoros Phokas, the emperor-to-be. Constantine's account of Nikephoros Phokas's achievements in the fights against the Arabs starts with the statement that the "hostile Arabs" had control over Crete which they had looted ${ }^{29}$. Then, Constantine highlights the military skills of Nikephoros Phokas who was put in charge of the fleet and sent to confront the Arabs in $\mathrm{Crete}^{30}$. The Byzantine author refers to the enemies as "amphibious beasts" and "brigands". Following a fierce struggle, they were defeated by Nikephoros, and their ships, referred to as pirate ships, were sunk. The emperor-to-be also easily captured their leader. Constantine Manasses concluded his description of the expedition with Nikephoros's triumphant return ${ }^{31}$.

In the account of Nikephoros Phokas's expedition to Crete we see Constantine Manasses's hostility towards the Arabs, one hand, but on the other hand, between the lines we can sense some sort of appreciation, given that Constantine emphasises Nikephoros won "shining trophies", and above all, that he had his triumph after the victory. For Monasses' reader it must have been obvious that this was a special distinction ${ }^{32}$ associated with a great victory over a mighty and dangerous opponent.

Having completed the account of the Crete expedition, Constantine Manasses still focuses on the reign of Romanos II and smoothly goes on to talk about how Antioch was taken over from the Arabs, which took place in 969, short before the death of Nikephoros Phokas, who had been the emperor for six years by then ${ }^{33}$. Constantine states that Antioch was conquered by "murderous Ishmaelites" and was treated like a disgraced slave or a harlot from the streets ${ }^{34}$. He does not mention, however, that this happened over three hundred years earlier ${ }^{35}$ and as a result we

\footnotetext{
${ }^{28}$ As a digression, the emperor himself is depicted in a negative light by Constantin Manasses: Synopsis Chronike, 5564-5568: Romanos handed over the entire rule and the whole empire to the evil and small-minded eunuchs. He himself was concerned with the hunt and the chase, and, like a demon, gawked at dog races (trans. - The Chronicle of Constantine Manasses, p. 221).

${ }^{29}$ Synopsis Chronike, 5568-5569.

${ }^{30}$ For more information about Nikephoros Phokas's expedition to Crete see: G.T. Tserebelakis,

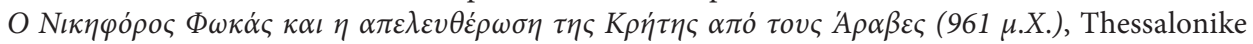
2009; A. Kaldellis, The Byzantine Conquest of Crete (961 ad), Prokopios' Vandal War, and the Continuator of the Chronicle of Symeon, BMGS 39, 2015, p. 302-311; IDEM, Streams of Gold, Rivers of Blood. The Rise and Fall of Byzantium, 955 ad. to the First Crusade, New York 2017, p. 34-38.

${ }^{31}$ Synopsis Chronike, 5575-5581.

${ }^{32}$ For more about the triumph ceremony see: M. McConmick, Eternal Victory. Triumphal Rulership in Late Antiquity, Byzantium, and Early Medieval West, Cambridge 1986. It should perhaps be mentioned that essentially only the emperor was entitled to triumph in the $10^{\text {th }}$ century.

${ }^{33}$ For more about the conquest of Antioch in 969 see: A. Kaldellis, Streams..., p. 63-64.

${ }^{34}$ Synopsis Chronike, 5582-5586 (trans. - The Chronicle of Constantine Manasses, p. 222).

${ }^{35}$ For more about the circumstances of the Arab conquest of Antioch in 636 see: G. DownEy, A History of Antioch in Syria to the Arab Conquest, Princeton-New Jersey 1961, p. 577-578.
} 
might get an impression that what Nikephoros Phokas did was a direct reaction to the Arab conquest of Antioch. The Byzantine author does not provide any details of the Byzantine Antioch takeover operation. He merely says that Nikephoros defeated his opponents who took delight in blood, and regained the elegant maiden with her fair complexion for the mother of beautiful children ${ }^{36}$.

In a fragment devoted to Nikephoros Phokas, providing no details whatsoever, Constantine Manasses mentioned his successes in the strife against the Arabs, concluding that the Arabs became frightened of him and the Syrians bowed before him; the Cilicians fled; the Phoenicians were suppressed ${ }^{37}$. The author takes this opportunity to exalt Nikephoros as brave and undefeated. This account shows a sense of pride when it comes to Nikephoros Phokas's achievements in the strife against the Arabs.

As for the Arabs during the reign of John Tzimiskes, our author writes that after coming into power he was in charge of the army as it fought the Arabs, and their leader Hamdan run away from John in great hurry. Further on he remarks that Arab commanders trembled at his strength. He mentions that also the Syrians had a taste of his sword and Phoenicians fled from his fiery hands. Manasses emphasizes that John built Byzantine fortifications even by the Tigris, he reached Edessa and the valley of the Euphrates which was filled with the neigh of his horses. We also learn about some activity on the territory of Cilicia ${ }^{38}$. This residual information matches what we know from other sources about the actions John Tzimiskes took against the Arabs ${ }^{39}$.

Even fuzzier are the Arab references when it comes to the reign of Basil II. Constantine points out that in the beginning of the emperor's rule many wars were being waged, including with the Arabs who destroyed Asia ${ }^{40}$. On the whole, as Manasses states, Basil subdued the Arabs ${ }^{41}$. It can be argued that Constantine Manasses singles out two major phases in Basil II's struggle against the Arabs. In the first one Arabs had the advantage, which seems to be due to the domestic wars taking place in the first phase of Basil's reign, while in the second phase Basil took the initiative and started to $\operatorname{win}^{42}$.

\footnotetext{
${ }^{36}$ Synopsis Chronike, 5589-5590 (trans. - The Chronicle of Constantine Manasses, p. 222).

${ }^{37}$ Synopsis Chronike, 5679-5680 (trans. - The Chronicle of Constantine Manasses, p. 226).

${ }^{38}$ Synopsis Chronike, 5786-5802.

${ }^{39}$ For more about the Byzantine-Arab relations during the reign of John Tzimiskes see: A. KALDELLIS, Streams..., p. 74-79.

${ }^{40}$ Synopsis Chronike, 5866-5867.

${ }^{41}$ Synopsis Chronike, 5877. What follows in the text is a list of peoples that were frightened of the emperor and accepted his sovereignty, which puts him in a most favourable light.

${ }^{42}$ Basic information on Basil's endeavour to stay on the Byzantine throne can be found in: J.-C. CHEYNET, Pouvoir et contestations à Byzance (963-1210), Paris 1990, p. 41sqq; C. Holmes, Basil II and Governance of Empire (976-1025), Oxford 2005. For more about Byzantine-Arab relations during
} 
To conclude this short discussion, it should be said that the Arabs were not a major topic for Constantine Manasses. They appear on the pages of Synopsis Chronike more seldom than could be expected based on how intense and important the relation with them was for the Byzantine. This could be explained by the small size of the chronicle which aimed to be a mere historical outline. In the process of writing, Constantine had to be strict when selecting his material ${ }^{43}$. In this sense, a rather significant consideration could have been that in his time Arabs posed no threat to the Byzantines. This might have prompted his decision to omit the phase of creating and developing the Arab statehood and its dynamic, in fact instant, expansion at the expense of, among others, Byzantium, which definitely did not fill him with pride and he thought he could refrain from talking about it. Of some (invariably small) interest to the author were only the episodes of Byzantine success, which were relatively recent with respect to when the chronicle was produced, and which can be ascribed to the activity of Nikephoros Phokas (first as a commander under Romanos II and then as an emperor) as well as John Tzimiskes and Basil II. Interestingly, all three were depicted by Constantine as excellent leaders and brave warriors. Victories over the Arabs are one of the elements that serve to build such an image.

When it comes to the earlier period, the Arabs seem to be referred to rather randomly and it is hard to ascertain why Manasses included these specific references. It could generally be said that they served the purpose of building the image - both positive and negative - of particular Byzantine rulers. Information about the Arabs was in this context a mere tool rather than a subject Manasses found interesting in itself.

It appears Manasses saw the Arabs primarily as bloody and cruel plunderers who invaded the Byzantine lands. Indeed, they won some of the fights against the Byzantines but eventually had to accept their superiority and concede defeat. It should also be noted that Constantine Manasses did not bring up religious themes when referring to the Arabs.

Translated by Mikołaj Deckert

the reign of Basil II see: W. FARAG, Byzantium and Its Muslim Neighbours during the Reign of Basil II (976-1025) (Ph.D. thesis, University of Birmingham 1977); C. Holmes, 'How the East Was Won' in the Reign of Basil II, [in:] Eastern Approaches to Byzantium, ed. A. EAstmond, Ashgate 2001, p. 41-56; A. KALDELlis, Streams..., p. 103-111.

${ }^{43}$ It seems reasonable to agree with the view expressed by Ingela NiLsson and Eva Nystrom (To compose..., p. 45) that Constantine Manasses includes and excludes episodes according to his own taste, which seems to be based on narrative potential rather than an historian's standard wish to 'tell everything. 


\section{Bibliography}

\section{Primary Sources}

Constantini Manassis Breviarium Chronicum, vol. I-II, rec. O. LAmpsidis, Athenis 1996 [Corpus fontium historiae byzantinae, 36.1-2].

Four Byzantine Novels. Agapetus - Theodore Prodromos. Rhodanthe and Dosikles - Eumathios Makrembolites. Hysmine and Hysminias. Constantine Manasses. Aristandros and Kallithea - Niketas Eugenianos, Drosilla and Charikles, trans. et praef. E. JEFFreYs, Liverpool 2012.

Horna K., Das Hoidonporikon des Konstantinos Manasses, "Byzantinische Zeitschrift" 13, 1904, p. 313-355.

Srednebolgarskij perevod chroniki Konstantina Manassii v slavjanskich literaturach, ed. D.S. LiCHAčEv, Sofija 1988.

The Chronicle of Constantine Manasses, trans. et praef. L. YuRETICH, Liverpool 2018.

\section{Secondary Literature}

BeEs N., Manassis, der Metropolit von Naupaktos ist identisch mit dem Schriftseller Konstantinos Manassis, "Byzantinisch-Neugriechische Jahrbücher" 7, 1928/1929, p. 119-130.

Boeck E.N., Displacing Byzantium, Disgracing Convention: the Manuscript Patronage of Tsar Ivan Alexander of Bulgaria, "Manuscripta: A Journal for Manuscript Research" 51, 2, 2007, p. 181-208.

Boeck E.N., Imagining the Byzantine Past. The Perception of History in the Illustrated Manuscripts of Skylitzes and Manasses, Cambridge 2015.

Boeck E.N., The Vatican Manasses as a Curated Display of Universal History, [in:] Laudator temporis acti. Studia in memoriam Ioannis A. Božilov, vol. II, Ius, imperium, potestas, litterae, ars et archeologia, ed. I. BILIARSKY, Serdicae 2018, p. 419-431.

CесотA B., Arabskie oblężenia Konstantynopola w VII-VIII wieku. Rzeczywistość i mit, Łódź 2015 [= Byzantina Lodziensia, 21].

Cheynet J.-C., Pouvoir et contestations à Byzance (963-1210), Paris 1990.

Conrad L.I., The Arabs to the Time of the Prophet, [in:] The Cambridge History of the Byzantine Empire c. 500-1492, ed. J. ShePARD, Cambridge 2007, p. 173-195.

Downey G., A History of Antioch in Syria to the Arab Conquest, Princeton-New Jersey 1961.

FARAG W., Byzantium and Its Muslim Neighbours during the Reign of Basil II (976-1025) (Ph.D. thesis, University of Birmingham 1977).

Gori E., Lo Hodoiporikon di Constantino Manasse, 2011 (= "Porphyra. La prima rivista online su Bisanzio" 8, ottobre 2011. Supplemento, 12).

Holmes C., Basil II and Governance of Empire (976-1025), Oxford 2005.

Holmes C., 'How the East Was Won' in the Reign of Basil II, [in:] Eastern Approaches to Byzantium, ed. A. Eastmond, Ashgate 2001, p. 41-56.

Hronikata na Konstantin Manasi. Zorata na bălgarskata epika, ed. et trans. I. BuJukLIEv, comm. I. BožILOv, Sofija 1992.

Jeffreys E., Sevastokratissa Eirene as Patron, "Wiener Jahrbuch für Kunstgeschichte" 61/62, 2011/2012, p. 177-194.

Jefrereys M., The Nature and Origins of the Political Verse, "Dumbarton Oaks Papers" 28, 1974, p. 141-195. 
KaEgi W.E., Byzantine Military Unrest. An Interpretation, Amsterdam 1981.

KaEgi W.E., Confronting Islam: Emperors versus Caliphs (641-c. 850), [in:] The Cambridge History of the Byzantine Empire c. 500-1492, ed. J. SHEPARD, Cambridge 2007, p. 365-394.

KaEgi W.E., Muslim Expansion and Byzantine Collapse in North Africa, Cambridge 2010.

Kaldellis A., The Byzantine Conquest of Crete (961 ad), Prokopios' Vandal War, and the Continuator of the Chronicle of Symeon, "Byzantine and Modern Greek Studies" 39, 2015, p. 302-311.

Kaldellis A., Streams of Gold, Rivers of Blood. The Rise and Fall of Byzantium, 955 a.d. to the First Crusade, New York 2017.

Kennedy H., The Great Arab Conquests. How the Spread of Islam Changed the World We Live in, London 2007.

LAmpsidis O., Eisagōgē, [in:] Constantini Manassis Breviarium Chronicum, vol. I, rec. O. LAMPsidis, Athenis 1996 [= Corpus fontium historiae byzantinae, 36.1], p. XI-CLIX.

Lampsidis O., Zur Biographie von Konstantinos Manasses und zur seiner Chronike synopsis (CS), "Byzantion. Revue internationale des études byzantines" 58, 1988, p. 97-111.

Lampsidis O., Zur Sebastokratorissa Eirene, "Jahrbuch der Österreichischen Byzantinistik" 34, 1984, p. 91-105.

Magdalino P., In Search of the Byzantine Courtier: Leo Choirosphaktes and Constantine Manasses, [in:] Byzantine Court Culture from 829 to 1204, ed. H. MAGUire, Washington 1997, p. 141-165.

Markovich M., The "Itinerary" of Constantine Manasses, "Illinois Classical Studies" 12, 2, 1987, p. $277-291$.

McCormicк M., Eternal Victory. Triumphal Rulership in Late Antiquity, Byzantium, and Early Medieval West, Cambridge 1986.

Neville L., Guide to Byzantine Historical Writing, coll. D. Harrisville, I. Tamarkina, C. WhatLEY, Cambridge 2018.

Nilsson I., Constantine Manasses, Odysseus and the Cyclops: On Byzantine Appreciation of Pagan Art in the Twelfth Century, "Byzantinoslavica. Revue internationale des études byzantines" 69, 2011, p. 123-136.

Nilsson I., Discovering Literariness in the Past: Literature vs. History in the Synopsis Chronike of Konstantinos Manasses, [in:] L'écriture de la mémoire: la litterarité de l'historiographie. Actes du colloque international sur la littérature byzantine, Nicosie 6-8 mai 2004, ed. P. Odorico, P.A. AGAPItos, M. Hinterberger, Paris 2006 [= Dossiers byzantins, 6], p. 15-31.

Nilsson I., Narrating Images in Byzantine Literature: the Ekphraseis of Konstantinos Manasses, "Jahrbuch der österreichischen Byzantinistik" 55, 2005, p. 121-146.

Nilsson I., The Past as Poetry: Two Byzantine World Chronicles in Verse, [in:] A Companion to Byzantine Poetry, ed. W. Hörandner, A. Rhoby, N. Zagklas, Leiden-Boston 2019, p. 517-538.

Nilsson I., Nystrom E., To Compose, Read, Use a Byzantine Texts: Aspects of the Chronicle of Constantine Manasses, "Byzantine and Modern Greek Studies” 33, 2009, p. 42-60.

Ostrogorski G., Dzieje Bizancjum, trans. H. Evert-Kappesowa et al., Warszawa 1968.

Praechter K., Eine vulgärgriechische Paraphrase der Chronik des Konstantinos Manasses, "Byzantinische Zeitschrift" 4, 1895, p. 272-313.

Praechter K., Zur vulgären Paraphrase des Konstantinos Manasses, "Byzantinische Zeitschrift" 7, 1898 , p. 588-593.

Sumner G.V., Phillipicus, Anastasius II and Theodosius III, "Greek, Roman, and Byzantine Studies" 17, 1976, p. 287-294. 
TAxidis I., Ekphraseis of Persons with Deviatonal Behavior in Constantine Manasses' Synopsis Chron-

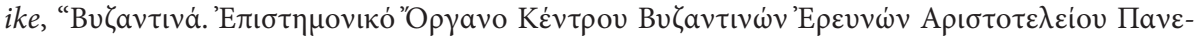
$\pi ı \tau \tau \mu$ íov" / "Byzantina. Epistēmoniko Organo Kentrou Byzantinōn Ereunōn Aristoteleiou Panepistēmiou" 35, 2017, p. 145-159.

Treadgold W., Seven Byzantine Revolutions and the Chronology of Theophanes, "Greek, Roman, and Byzantine Studies" 31, 1990, p. 203-227.

Tserebelakis G.T., O Nikēforos Fōkas kai è apeleutherōsē tēs Krētēs apo tous Arabes (961 m.Ch.), Thessalonike 2009.

VAsıl'ev A.A., Vizantija i araby. Političeskie otnošenija za vremja Makedonskoj dinastii (867-959), Sankt-Peterburg 1902.

Wolińska T., Arabs, (H)agarenes, Ishmaelites, Saracens - a Few Remarks about Naming, [in:] Byzantium and the Arabs. The Encounter of Civilizations from Sixth to Mid-Eighth Century, ed. T. Wolińska, P. Filipczak, Łódź 2015 [= Byzantina Lodziensia, 22], p. 22-37.

Wolı́́ska T., Difficult Neighbours, Enemies, Partners, Allies, [in:] Byzantium and the Arabs. The Encounter of Civilizations from Sixth to Mid-Eighth Century, ed. T. Wolińska, P. Filipczak, Łódź 2015 [= Byzantina Lodziensia, 22], p. 150-203.

Yuretich L., Introduction, [in:] The Chronicle of Constantine Manasses, trans. et praef. L. Yuretich, Liverpool 2018, p. 1-17.

ŽARKaja V.Ju., Neskol'ko zamečanij o složnych èpitetach u Konstantina Manassii, “Античная древность и средние века" / “Antičnaja drevnost' i srednie veka” 44, 2016, p. 178-190.

\begin{abstract}
This paper looks into the piece by Constantine Manasses considering how it depicts the Arabs. It appears Manasses saw the Arabs primarily as bloody and cruel plunderers who invaded the Byzantine lands. Indeed, they won some of the fights against the Byzantines but eventually had to accept their superiority and concede defeat. It should also be noted that Constantine Manasses did not bring up religious themes when referring to the Arabs.
\end{abstract}

Keywords: Arabs, Constantine Manasses, Byzantine historiography.

Mirosław J. Leszka

University of Łódź

Faculty of Philosophy and History

Department of Byzantine History

ul. Kamińskiego 27a

90-219 Łódź, Poland miroslaw.leszka@uni.lodz.pl 